\title{
Automated Landform Classification of China Based on Hammond's Method
}

\author{
Baoying Ye \\ School of Land Science and Technology, China University of Geosciences, Beijing, China \\ Email: yebaoying@cugb.edu.cn
}

How to cite this paper: Ye, B.Y. (2020) Automated Landform Classification of China Based on Hammond's Method. Journal of Computer and Communications, 8, 23-30. https://doi.org/10.4236/jcc.2020.86003

Received: June 1, 2020

Accepted: June 26, 2020

Published: June 29, 2020

\begin{abstract}
The automatic classification of Macro landforms was processed with the program developed by Hammond's Manual procedures, which based on properties of slope, local relief, and profile type, which consists of 5 landform types, 24 landform class and 96 landform subclasses. This program identified landform types by moving a square window with size of $9.8 \mathrm{~km} \times 9.8 \mathrm{~km}$. The data includes 816 sheets of topological map with a scale of 1:250,000. The DEM were buildup with the contours and mark points based on this data with a cell size of $200 \mathrm{~m}$, and merge into one sheet. The automated classification was processed on this DEM data with a AML program of ArcGIS 10.X Workstation. The result indicates it produced a classification that has good resemblance to the landforms in China. The maps were produced respectively with 5 types, 16 classes and, 90 subclasses The 5 Landform types of landforms were Plains (PLA), 20.25\% of whole areas; Tablelands (TAB) of 3.56\%; Plains with Hills or Mountains (PHM) of 32.84\%; Open Hills and Mountains (OHM) of 18.72\%; Hills and Mountains (HM) of $24.63 \%$. In the result of 24 landform classes, there are not some classes, such as irregular plains with low relief; open very low hills, open low hills; very low hills, low hills, moderate hills. The result of 96 landform subclass is similar to the 24 class.
\end{abstract}

\section{Keywords}

Landform Classification, Hammond, DEM

\section{Introduction}

To some degree, landforms influence the distribution and evolution of ecology and other environmental factor, which is the core and the basic content of geography [1]. Landform morphological classification is the basic unit of landform, and also the first step in solving geomorphic problems. The landform classifications of large scale were started in 1950 in China. In 1956, the 1:4,000,000 Landform Clas- 
sifications and Region Planning Map of China, according to the altitude and surface cutting degree (Table 1). In 1979, the Mapping Standard of 1:1,000,000 Landform Classifications in China were completed, and classified the landform types with the altitude, relative altitude and the surface cutting degree, according to the classification schemes of 3.А.Сварицевская (1975). Until 1989, only 15 sheets landform maps (1:1,000,000 scale) were completed. This mission was suspended for a long time. Until 2009, the 1:1,000,000 scale landform atlases of whole China is accomplished [2]. The two landform classifications schemes above, is based on manual process.

The 1:40,000,000's scheme is based on forms and exogenic forces, and many parameters are not quantitative. There were many quantitative factors is introduced into the 1:1,000,000's scheme, such as altitude, local relief, and slope. The local relief is classified into 4 classless, less than $500 \mathrm{~m}$ is low relief hills; $500-1000 \mathrm{~m}$ is moderate relief hills, $1000-2500 \mathrm{~m}$ is high relief mountains and more than $2500 \mathrm{~m}$ is very high relief mountains [3]. There are also some papers adopted local reliefs but different classes in whole China's landform scheme. Cai Zongxin (1986) classified grade into 5 classes, less than $20 \mathrm{~m}$ is plains; $20-200 \mathrm{~m}$ is hills, 200 - 500 is low mountains, $500-1500 \mathrm{~m}$ is middle mountains and more than $1500 \mathrm{~m}$ is high mountains (Table 2) [3]. Tu Hanming et al. [4] classified local relief of China into 7 classes based on the statistics of samples from whole China's DEMs. In 2009, Zhou Chenghu et al., classified the landform of China into 7 types and 25 classes, according to slope, relief and altitude (Table 3).

In 1990's, there are some scholars contributing to extracting the single landform parameters in China, such as ridge line and valley line [5] [6] [7], summit [8], shoulder line of valleys [9] [10], micro topography [11]. All above are based on the regions of simple landforms evolutions. There are many limits to automatically whole China's landform classifications. Liu Aili et al. (2006) [12] attempted to automate classify the landforms of whole China based on image classifications methods. But the sampling cell is $1000 \mathrm{~m} \times 1000 \mathrm{~m}$, which is coarse enough to omit many small landform units.

Table 1. Mountain and hills classification of China.

\begin{tabular}{cccc}
\hline Class & Subclass & Altitude $(\mathrm{m})$ & Surface cutting degree \\
\hline Extremely high mountain & & $>5000$ & $>1000$ \\
\hline \multirow{2}{*}{ High mountain } & High mountain & $>1000$ \\
& Mid-high mountain & $3500-5000$ & $500-1000$ \\
& Low-high mountain & $<500$ \\
\hline \multirow{2}{*}{ Middle mountain } & High-middle mountain & $>1000$ \\
& Middle mountain & $1000-3500$ & $500-1000$ \\
Low mountain & Low-middle mountain & & $<500$ \\
\hline Hills & Mid-low mountain & $500-1000$ & $100-500$ \\
\hline
\end{tabular}


Table 2. The basic geomorphologic index of China.

\begin{tabular}{cc}
\hline Types & Relative altitude \\
\hline Plain & $<20$ \\
Hills & $20-200$ \\
Low mountain & $200-500$ \\
Middle mountain & $500-1500$ \\
High mountain & $>1500$ \\
\hline
\end{tabular}

Table 3. Basic morphological types of land geomorphology in China.

\begin{tabular}{|c|c|c|c|c|}
\hline Altitude & Low altitude & Mid-altitude & High altitude & $\begin{array}{l}\text { Extremely high } \\
\text { altitude }\end{array}$ \\
\hline relief & $<1000$ & $1000-3500$ & $3500-5000$ & $>5000$ \\
\hline Plain $(<30)$ & Low altitude plain & $\begin{array}{l}\text { Mid-altitude } \\
\text { plain }\end{array}$ & $\begin{array}{l}\text { High altitude } \\
\text { plain }\end{array}$ & $\begin{array}{l}\text { Extremely high } \\
\text { altitude plain }\end{array}$ \\
\hline Platform > 30 & $\begin{array}{l}\text { Low altitude } \\
\text { platform }\end{array}$ & $\begin{array}{l}\text { Mid-altitude } \\
\text { platform }\end{array}$ & $\begin{array}{l}\text { High altitude } \\
\text { platform }\end{array}$ & $\begin{array}{l}\text { Extremely high } \\
\text { altitude platform }\end{array}$ \\
\hline Hills $<200$ & Low altitude hills & Mid-altitude hills & High altitude hills & $\begin{array}{l}\text { Extremely high } \\
\text { altitude hills }\end{array}$ \\
\hline $\begin{array}{l}\text { Small-relief } \\
\text { mountain } \\
200-500\end{array}$ & $\begin{array}{l}\text { Small-relief low } \\
\text { mountain }\end{array}$ & $\begin{array}{l}\text { Small-relief } \\
\text { mid-mountain }\end{array}$ & $\begin{array}{l}\text { Small-relief high } \\
\text { mountain }\end{array}$ & $\begin{array}{c}\text { Small-relief } \\
\text { Extremely high } \\
\text { mountain }\end{array}$ \\
\hline $\begin{array}{l}\text { Mid-relief } \\
\text { mountain } \\
500-1000\end{array}$ & $\begin{array}{l}\text { Mid-relief low } \\
\text { mountain }\end{array}$ & $\begin{array}{c}\text { Mid-relief } \\
\text { mid-mountain }\end{array}$ & $\begin{array}{c}\text { Mid-relief } \\
\text { high mountain }\end{array}$ & $\begin{array}{c}\text { Mid-relief } \\
\text { Extremely high } \\
\text { mountain }\end{array}$ \\
\hline $\begin{array}{c}\text { Big-relief } \\
\text { mountain } \\
1000-2500\end{array}$ & & $\begin{array}{c}\text { Big-relief } \\
\text { mid-mountain }\end{array}$ & $\begin{array}{c}\text { Big-relief } \\
\text { high mountain }\end{array}$ & $\begin{array}{c}\text { Big-relief } \\
\text { Extremely } \\
\text { high mountain }\end{array}$ \\
\hline Extremely & & & Extremely & Extremely \\
\hline $\begin{array}{c}\text { Big-relief } \\
\text { mountain }>2500\end{array}$ & & & $\begin{array}{c}\text { Big-relief } \\
\text { high mountain }\end{array}$ & $\begin{array}{c}\text { Big-relief Extremely } \\
\text { high mountain }\end{array}$ \\
\hline
\end{tabular}

In this paper, we classified the landform of whole China in Hammond's scheme according of slope, local relief, and profile type [13] [14]. We compare the result with and the scheme by Zhou Chenghu et al. (2009) [2]. The computer-program is based on the approach developed by Dikau et al. [15]. In order to compare with the international landform maps, the parameters of Hammond's scheme are kept unchanged.

\section{Hammond Landform Classification}

\subsection{Concept}

Hammond's hierarchic landform classification is based on properties of slope, localrelief, and profile type.

1) The slope is divided into 4 levels based on the percent of area gently sloping. If the inclination is below $8 \%$, we call this gently slope (Figure 1 ). The percent area is calculated in moving widow $(9.8 \mathrm{~km} \times 9.8 \mathrm{~km})$. 


\begin{tabular}{|c|c|c|c|}
\hline $\mathrm{A}$ & $\mathrm{A}$ & $\mathrm{A}$ & $\mathrm{A}$ \\
\hline $\mathrm{B}$ & $\mathrm{A}$ & $\mathrm{D}$ & $\mathrm{D}$ \\
\hline $\mathrm{B}$ & $\mathrm{D}$ & $\mathrm{C}$ & $\mathrm{D}$ \\
\hline $\mathrm{B}$ & $\mathrm{D}$ & $\mathrm{D}$ & $\mathrm{C}$ \\
\hline
\end{tabular}

Figure $1 . \%$ area local gently sloping $(4 \times 4)$. A: $31.25 \%$, B: $18.75 \%$, C: $37.5 \%$, D: $12.5 \%$.

2) Local relief is the difference between maximum and minimum elevation in moving window. Local relief had a non-linear relationship with horizontal length by examining a variety of mountain belts [16]. Tu Hanming et al. [4]-[17] calculated the length scale with the sampling data from the whole land China, 5 optimum statistical length was calculated corresponding to different map scale, which is $2,6,16,20,22\left(\mathrm{~km}^{2}\right)$. In this paper, we choose the $9.8 \mathrm{~km} \times 9.8 \mathrm{~km}$ in order to compare with the Hammond's classification.

3) Profile type subdivide tablelands as upland units and plains with hills or mountains as lowland unit [15].

With these three parameters, Hammond classified 96 landform subclasses theoretically (Table 4, Table 5). Hammond used only 45 subclasses were common in U.S. [18]. He generalized his results by merging areas smaller than $2072 \mathrm{~km}^{2}$ into adjacent units to avoid cluttering at a 1:5,000,000 map. Dikau et al. [15] developed automated approach identified all 96 landforms units without generalization.

\subsection{Method}

The data were processed in ArcGIS 10.x Workstation with 64 bit windows OS in Hp xw8400. The Python and ARC/INFO AML were the scripting languages for batching the data. The procedures mainly include two steps, the DEM buildup and automated classification:

The DEM buildup: The contours and mark points features were extracted from the terrain layer. For eliminating the boundary effect, 16 sheets merge into one map before generation of DEM, then clipping the DEM with the boundary of one sheet. The whole China consists of 61 maps with a scale of 1:1,000,000. The DEM were buildup with the contours and mark points with ARC/INFO command of "generate $<>$ ", and merge into one sheet with $100 \mathrm{~m}$.

Automated classification: The DEM were resampled into $200 \mathrm{~m}$. The moving window is $49 \times 49(9.8 \mathrm{~km} \times 9.8 \mathrm{~km})$. The three parameter layers were derived from DEM firstly, and then they were overplayed to generate one 96 -subclasses landform map. A AML was developed according to the Dikau's approach. We merged the three parameter layers to yield a landforms map. 
Table 4. Hammond's landform classification.

\begin{tabular}{ccc}
\hline Percent of area gently sloping & Local relief & Profile type \\
\hline 1) more than 80 & $1.0-30$ & $1 .>75 \%$ in lowland \\
2) $50-80$ & $2.30-91$ & $2.50 \%-75 \%$ in lowland \\
3) $20-50$ & $3.91-152$ & $3.25 \%-50 \%$ in lowland \\
4) less than 20 & $4.152-305$ & $4 .<25 \%$ in lowland \\
& $5.305>914$ & \\
\hline
\end{tabular}

Table 5. The landform classifications of China.

\begin{tabular}{|c|c|c|c|c|c|c|c|c|}
\hline \multicolumn{2}{|l|}{ Landform } & \multicolumn{2}{|l|}{ Class } & \multicolumn{5}{|c|}{ Subclass } \\
\hline \multirow{2}{*}{$\begin{array}{c}5 \text { types } \\
\text { Plains (PLA) }\end{array}$} & \multirow{2}{*}{$\begin{array}{l}\text { area\% } \\
20.25\end{array}$} & \multirow{2}{*}{$\frac{24 \text { classes }}{\text { flat or nearly flat plains }}$} & \multirow{2}{*}{$\begin{array}{c}\text { area\% } \\
10.86\end{array}$} & \multirow{2}{*}{$\begin{array}{c}96 \text { subclasses } \\
111,112,113,114\end{array}$} & \multicolumn{4}{|c|}{ area\% } \\
\hline & & & & & 3.41 & 3.15 & 2.64 & 1.67 \\
\hline & & smooth plains with some local relief & 9.37 & $121,122,123,124$ & 4.78 & 2.51 & 1.52 & 0.56 \\
\hline & & irregular plains with moderate relief & 0.02 & $221,222,223,224$ & 0.02 & 0.01 & & \\
\hline \multirow[t]{4}{*}{ tablelands (TAB) } & 3.56 & tablelands with moderate relief & 1.34 & $133,134,233,234$ & 1.04 & 0.27 & 0.02 & \\
\hline & & tablelands with considerable relief & 1.50 & $143,144,243,244$ & 0.77 & 0.22 & 0.38 & 0.13 \\
\hline & & tablelands with high relief & 0.70 & $153,154,253,254$ & 0.10 & 0.05 & 0.37 & 0.19 \\
\hline & & tablelands with very high relief & 0.03 & $163,164,263,264$ & 0.01 & & 0.01 & 0.01 \\
\hline \multirow[t]{4}{*}{$\begin{array}{l}\text { plains with hills or } \\
\text { mountains (PHM) }\end{array}$} & 32.84 & plains with hills & 7.25 & $131,132,231,232$ & 4.73 & 2.17 & 0.20 & 0.15 \\
\hline & & plains with high hills & 12.64 & $141,142,241,242$ & 7.10 & 1.89 & 2.84 & 0.80 \\
\hline & & plains with low mountains & 12.45 & $151,152,251,252$ & 3.19 & 0.29 & 8.04 & 0.93 \\
\hline & & plains with high mountains & 0.50 & $161,162,261,262$ & 0.04 & 0.00 & 0.46 & 0.01 \\
\hline \multirow[t]{3}{*}{$\begin{array}{c}\text { Open hills and } \\
\text { mountains (OPM) }\end{array}$} & 18.72 & open high hills & 1.14 & $341,342,343,344$ & 0.44 & 0.41 & 0.24 & 0.05 \\
\hline & & open low mountains & 14.85 & $351,352,353,354$ & 10.37 & 2.53 & 1.34 & 0.61 \\
\hline & & open high mountains & 2.73 & $361,362,363,364$ & 2.25 & 0.19 & 0.12 & 0.16 \\
\hline \multirow[t]{2}{*}{$\begin{array}{c}\text { Hills and } \\
\text { mountains (HMO) }\end{array}$} & 24.63 & low mountains & 7.10 & $451,452,453,454$ & 3.73 & 2.08 & 0.99 & 0.30 \\
\hline & & high mountains & 17.52 & $461,462,463,464$ & 7.29 & 5.19 & 3.27 & 1.78 \\
\hline
\end{tabular}

\section{Study Area and Data}

This automated process was tested on almost whole China, which consists of mainland, Hainan and Taiwan islands. The data includes 816 sheets of topological map with a scale of 1:250,000, which were digitalized by National Geometrics Center of China in 1998. The content consists of 14 layers: hydrological system, Residential, Railway, Road, boundary, Terrain, and some auxiliary ones. The terrain data include contours and mark point, and the contours interval is 50 or $100 \mathrm{~m}$. 


\section{Result and Analysis}

The maps were constructed respectively with 5 types, 16 classes and 90 subclasses (Table 2, Figure 2, Figure 3). The whole area of China is $9482552.72 \mathrm{~km}^{2}$ besides some small island were not calculated. The 5 Landform types of landforms were Plains (PLA), 20.25\% of whole areas; Tablelands (TAB) of 3.56\%; Plains with Hills or Mountains (PHM) of 32.84\%; Open Hills and Mountains (OHM) of $18.72 \%$; Hills and Mountains (HM) of 24.63\%. The PLA were located in Songnen Plain, Sanjiang Plain, Huabei Plain, Huaihai Plain, Jianghai Plain, Aletai Basin, Talimu Basin, Loess Plateau, etc. The TAB were scattered in whole China, which each patch is small. The PHMs were located in Xiao-Xing'anling Mountains, Shandong peninsula, Inner-Mongolian, Qinghai-Tibet Plateau, Sichuan Basin, Guangxi and Hunan province. The OHM were located in Da-Xing'anling Mountains, Shaanxi province, Guizhou province and scatted in North of Tibet Plateau. The HMO is located in East of Tibet Plateau, around the Sichuan Basin, Yunnan, Fujian Taiwan province. The result indicates it produced a classification that has good resemblance to the landforms in China.

Some classes were not generated, such as irregular plains and low hill. The PLA is primary flat or smooth without some relief. The altitude in hill or mountain region is high, so there are almost not low hill.

According to Hammond's scheme, the area of TAB is only $3.56 \%$. The area of tableland in some manual scheme is much more than that [19]. There are several large tablelands, such as Qinghai-Tibet Plateau, Mongolia Plateau, Loess Plateau,

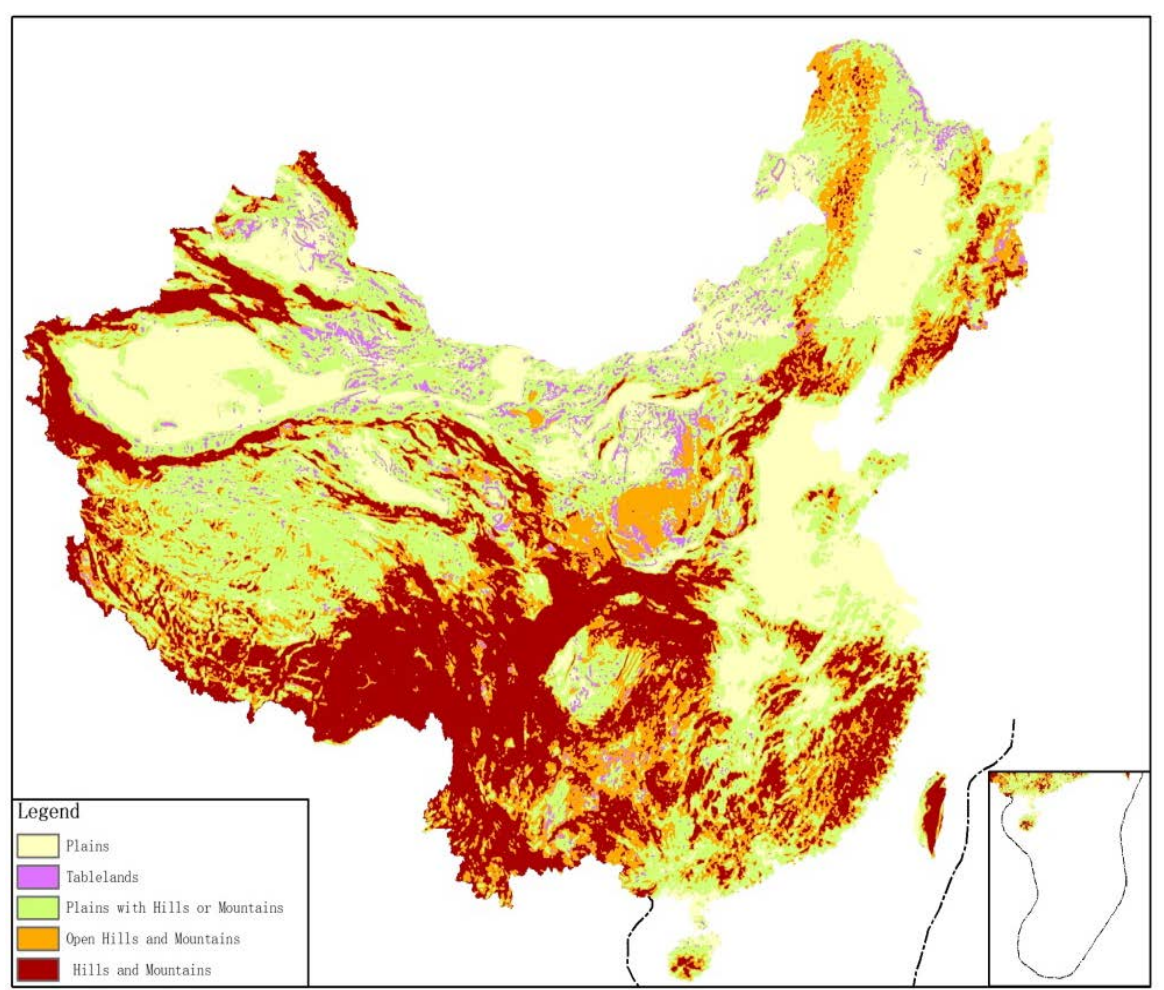

Figure 2. 5-type landforms map of China land. 


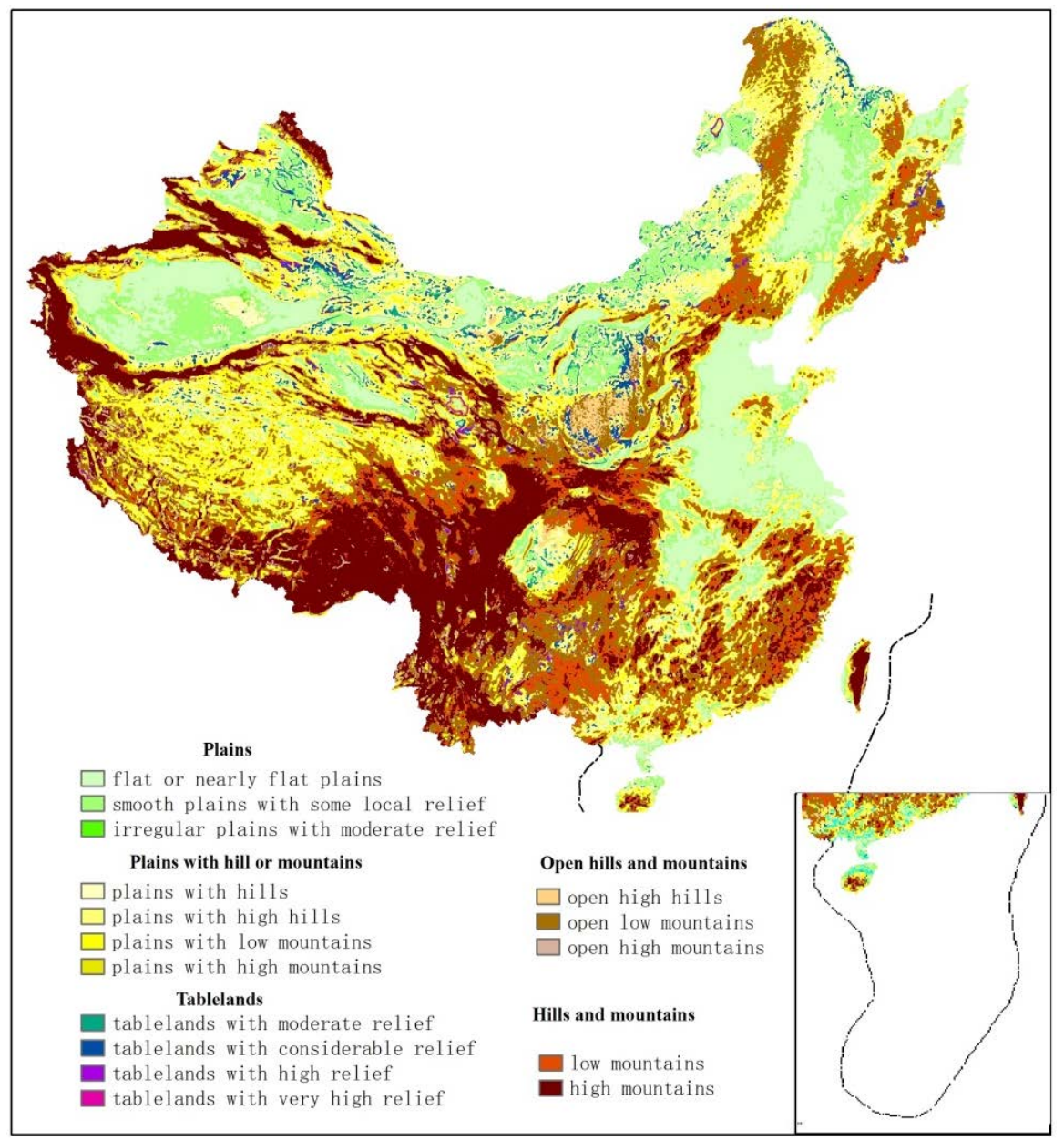

Figure 3. 24-classes landforms map of China land.

Yun-gui Plateau. In Figure 2, Qinghai-Tibet Plateau is mainly classified into PHM; Mongolia Tableland and Loess Tableland is classified into PLA or PHM and the Yun-gui Tableland is classified into HMO. There are many hills or mountains in tableland in China. The basin is basically classified into PLA, but the Sichuan Basin is mainly classified into PHM or PLA.

\section{Conclusion}

Automated landform classification produced a classification that has good resemblance to those of manual approach. However, some classes are different from manual method. There are much more complex landform in China, and the geomorphologic evolution is much more different, so it needs to improve the method to classified more reasonable. Furthermore, the effects of scale and generalization also should be paid special attention.

\section{Conflicts of Interest}

The author declares no conflicts of interest regarding the publication of this paper. 


\section{References}

[1] Yan, S.X. (1985) Geomorphology. Shanghai High Education Press.

[2] State Key Laboratory of Resources and Environmental Information System (2009).

[3] Su, S.Y. and Li, J.Z. (1998) Geomorphology Mapping.

[4] Tu, H.M. and Liu, Z.D. (1991) Study on Amplitude in China. Acta Geodaetica et Cartographica Sinica, 20, 311-319.

[5] Liu, Z.H. and Huang, P.Z. (2003) Derivation of Skeleton Line from Topographic Map with DEM Data. Science of Surveying and Mapping, 28, 33-38.

[6] Jin, H.L., Gao, J.X. and Kang, J.R. (2005) A Study of Extracting Terrain Feature Lines Based on Vector Contour Data. Bulletin of Surveying and Mapping, 67, 54-55.

[7] Qu, J.H., Cheng, J.L. and Cui, X.G. (2007) Automatic Extraction for Ridge and Valley by Vertical Sectional Method. Science of Surveying and Mapping, 32, 33-34.

[8] Chen, P.P., Zhang, Y.S., Wang, C., et al. (2006) Method of Extracting Surface Peaks Based on DEM. Modern Surveying and Mapping, 29, 11-13.

[9] Lu, G.N., Qian, Y.D. and Chen, Z.M. (1998) Study of Automated Extraction Of Shoulder Line of Valley from Grid Digital Elevation Data. Scientia Geographica Sinica, 18, 567-573.

[10] Liu, P.J., Zhu, Q.K., Wu, D.L., et al. (2006) Automated Extraction of Shoulder Line of Valleys Based on Flow Paths from Grid Digital Elevation Model (DEM) Data. Journal of Beijing Forestry University, 28, 72-75.

[11] Zhou, F.B. and Liu, X.J. (2008) Research on the Automated Classification of Micro Landform Based on Grid DEM. Journal of Wuhan University of Technology (Information \& Management Engineering), 30, 172-175.

[12] Liu, A.L. and Tang, G.A. (2006) DEM Based Auto-Classification of Chinese Landform. Geo-Information Science, 8, 8-14.

[13] Hammond, E.H. (1954) Small-Scale Continental Landform Maps. Annals of the Association of American Geographers, 44, 33-42. https://doi.org/10.1080/00045605409352120

[14] Hammond, E.H. (1964) Analysis of Properties in Land Form Geography: An Application to Broad-Scale Land form Mapping. Annals of the Association of American Geographers, 54, 11-19. https://doi.org/10.1111/j.1467-8306.1964.tb00470.x

[15] Dikau, R., Brabb, E.E. and Mark, R.M. (1991) Landform Classification of New Mexico by Computer. U.S. Geological Survey, Menlo Park, CA, Open-File Report 91-634. https://doi.org/10.3133/ofr91634

[16] Ahnert, F. (1984) Local Relief and the Height Limits of Mountain Ranges. American Journal of Science, 284, 1035-1055. https://doi.org/10.2475/ajs.284.9.1035

[17] Tu, H.M. and Liu, Z.D. (1990) Demonstrating on Optimum Statistics Unit of Relief Amplitude in China. Journal of Hubei University(Natural Science), 20, 311-319.

[18] Brabyn, L. (1998) GIS Analysis of Macro Landform. Presented at the 10th Ann. Colloquium Spatial Information Research Centre University of Otago. http://www.waikato.ac.nz/wfass/subjects/geography/staff/lars/landform/sirc98.html

[19] Chen, Z.M. (1993) 1:4,000,000 Geomorphologic Map of China and Its Adjacent Area. China Map Press. 